\title{
MONITOREO DE LOS MATERIALES ESCRITOS Y DE LOS PUESTOS DE INFORMACIÓN DE UNA CAMPAÑA EDUCATIVA PARA AUMENTAR EL CONSUMO DE FRIJOLES ${ }^{1}$
}

\author{
MONITORING OF PRINTED MATERIALS AND INFORMATION STANDS OF \\ AN EDUCATIONAL CAMPAIGN TO INCREASE BEAN CONSUMPTION1
}

\author{
Marcela Dumani², Elizabeth López ${ }^{3}$
}

\begin{abstract}
RESUMEN
Monitoreo de los materiales escritos y de los puestos de información de una Campaña educatitva para aumentar el consumo de frijoles. Se presentan los resultados del monitoreo de los principales materiales educativos y de algunas actividades interactivas desarrolladas en la etapa de ejecución de una Campaña educativa para incrementar el consumo de frijoles. El estudio incluye el seguimiento de un recetario y dos panfletos desplegables, así como de los puestos promocionales ubicados en los supermercados. Los materiales y las actividades de la Campaña fueron elaborados y planeados tomando en cuenta los criterios aportados por la población que participó en la etapa diagnóstica de la investigación. Para valorar la contribución a la Campaña del material y las actividades educativas ya mencionadas, se obtuvieron las opiniones de la población hacia la cual iban dirigidos. Esto permitió, determinar su utilidad para campañas o programas educativos similares en el futuro. El recetario "De Todo con Frijoles" constituyó un recurso importante para la Campaña. Este material tuvo una amplia aceptación por parte de las madres. El monitoreo aplicado a los panfletos desplegables permitió confirmar que las mujeres valoran la información que se ofrece en un material educativo impreso y que la forma de ilustrarlo y presentarlo, complementan la información y captan la atención de la población. Las actividades interactivas son importantes en una campaña educativa, ya que permiten el contacto directo con la población, la evacuación de dudas y la generación de información adicional sobre las percepciones que tienen las personas en relación con el alimento que se promueve. El monitoreo de estas actividades posibilitó realizar ajustes sobre la marcha que favorecieron el cumplimiento de los objetivos de la Campaña..
\end{abstract}

Palabras claves: monitoreo, evaluación formativa, materiales educativos, Campaña educativa.

1 Recibido para publicación el 30 de junio del 2004. Este artículo se deriva de la investigación desarrollada en el Proyecto Campaña Educativa para Promover el Consumo de Frijoles, de la Escuela de Nutrición de la UCR, inscrito dentro del proyecto macro "Mejoramiento de la Digestibilidad del Frijol", CITA, UCR, bajo el auspicio del Programa Bean/Cowpea CRSP; USAID Grant DANG-SS-86-0008-88.

2 Escuela de Nutrición, Universidad de Costa Rica. E mail: mdumani@racsa.co.cr.

3 Colaboradora, Escuela de Nutrición, Universidad de Costa Rica.

\begin{abstract}
Monitoring of printed materials and information stands of an educational campaign to increase bean consumption. The results of monitoring the main educational materials and some interactive activities carried out during implementation of an educational Campaign to increase bean consumption are presented in this article. The study included the follow-up on a recipe book, two different brochures, and promotional stands located in supermarkets. The Campaign's materials and activities were made and planned taking into account the criteria of the people participating in the study's initial assessment. In order to assess the contribution of the above mentioned materials and educational activities to the Campaign, opinions about them were obtained from the target population. This was also helpful to determine their usefulness for other similar educational campaigns or programs to be implemented in the future. The recipe book "De todo con Frijoles" was an important resource for the Campaign. This material was widely accepted by all mothers. Monitoring the brochures made it possible to confirm that mothers highly appreciate information received as printed educational material, and that the way such information is illustrated and presented is important to get people's interest. Interactive activities are important in educational campaigns, because they facilitate direct contact with the population, allow responding questions that might arise, and help obtain additional knowledge about people's perception with regards to the food being promoted. Following up on these activities made it possible to introduce the necessary changes as the Campaign advanced, which helped to meet the objectives.
\end{abstract}

Key words: monitoring, follow-up evaluation, educational materials, educational Campaign.

\footnotetext{
1 Received for publication on June 30, 2004. This article is the result from the investigation carried out in the Project "Educational Campaign to Increase Bean Consumption", from the University of Costa Rica's Nutrition School, which is part of the macro-project "Improving Digestibility of Beans", CITA, UCR, sponsored by the Bean/Cowpea CRSP Program; USAID Grant DAN-G-SS-86-0008-88.

2 University of Costa Rica, School of Nutrition. E-mail: mdumani@racsa.co.cr
} 


\section{INTRODUCCIÓN}

Este trabajo, es parte del proyecto Campaña educativa para incrementar el consumo de frijoles. Presenta los resultados del monitoreo de los principales materiales educativos elaborados para la Campaña (un recetario y dos panfletos desplegables) y de las actividades interactivas desarrolladas en los puestos promocionales en supermercados.

El monitoreo, llamado también evaluación formativa, procura evaluar el desarrollo de un proceso y de las actividades programadas, así como aportar información sobre las situaciones que van surgiendo durante la ejecución de lo planificado. Esta evaluación puede ser expresada a través de indicadores cualitativos y/o cuantitativos (FAO 1995).

El monitoreo, es importante porque permite controlar la calidad y pertinencia de los materiales educativos y de las actividades interactivas planeadas y realizar, sobre la marcha, los ajustes que sean necesarios (FAO 1993). En este caso, el monitoreo permite también proponer materiales apropiados para otras actividades educativas sobre este alimento que se puedan realizar en el futuro.

Para cumplir con el propósito de la evaluación formativa y poder realimentar el proceso, es necesario obtener información cualitativa que refleje las opiniones de la población con respecto a los diferentes componentes del mismo (Hurtado 1999) ${ }^{4}$.

Las experiencias en diferentes trabajos de evaluación demuestran que la evaluación por sí misma constituye un instrumento de aprendizaje de gran valor, además de cumplir los objetivos propios de la evaluación de proyectos. Según OMS, citado en Cohen y Franco (Cohen y Franco 1997), el propio proceso de evaluación puede ser tan importante como las conclusiones a las que conduzca, ya que la participación permite comprender mejor las actividades que se evalúan y enfocar de modo más constructivo su ejecución y las necesidades de acción futuras.

El monitoreo permite la recolección de información continua y su oportuna revisión durante la ejecución del proyecto; además provee información de contexto para las evaluaciones posteriores (Hurtado 1999) ${ }^{5}$. Gracias al carácter iterativo de la metodología cualitativa, este tipo de evaluación ayuda a los responsables

\footnotetext{
4-5 Hurtado, E. 1999. Evaluación cualitativa. Antropóloga e investigadora del Instituto de Nutrición de Centroamérica y Panamá (INCAP). Guatemala. Comunicación personal.
}

\section{INTRODUCTION}

This work is part of the Project Educational Campaign to Increase Bean Consumption. It presents the results of monitoring the main educational materials produced for the Campaign (a recipe book and two brochures), and the interactive activities carried out in promotional stands in supermarkets.

Monitoring, also called follow-up evaluation, is intended to assess the implementation of processes and scheduled activities, and to provide information on situations that arise during implementation. This evaluation may be expressed in the form of quantitative or qualitative indicators (FAO 1995).

Monitoring is important because it facilitates controlling both the quality and suitability of educational materials and planned interactive activities, in order to make ongoing changes (FAO 1993). In this case, monitoring will also make it possible to propose appropriate materials for other bean-related educational activities that may be carried out in the future.

In order to comply with the purpose of the follow up evaluation and obtain feedback on the process, it is necessary to collect qualitative information showing public opinions with respect to its different components (Hurtado 1999) 4 .

Previous experiences in different evaluation efforts show that the assessment is in itself a highly valuable learning tool, and it also meets the objectives pertaining to project assessment. According the WHO, quoted in Cohen and Franco (Cohen and Franco 1997), the assessment process itself can be as important as the conclusions it leads to. Participation facilitates a better understanding of the activities evaluated, and helps focus their implementation and further actions in a more constructive manner

Monitoring permits continuous collection of data, and ongoing review of project implementation; it also provides contextual information for further assessments (Hurtado 1999) ${ }^{5}$. Because of the iterative nature of qualitative methodologies, this type of assessment allows those responsible for the project to make changes in the objectives, implementation strategies, or other aspects, if necessary.
4-5 Hurtado, 1999. Qualitative evaluation. Anthropologist/ Researcher. Instituto de Nutrición de Centroamérica y Panamá (INCAP), Guatemala. Personal communication. 
del proyecto a realizar ajustes en los objetivos, en las estrategias de implementación o en otros aspectos, en caso necesario.

El trabajo tuvo como objetivo evaluar el desarrollo de las actividades y la pertinencia de los materiales que se estaban utilizando en el momento de la ejecución de la Campaña. Los elementos que se presentan en este artículo, fueron fundamentales para la difusión de los mensajes durante la Campaña.

\section{MATERIALES Y MÉTODOS}

Este trabajo presenta el monitoreo de los siguientes materiales elaborados para la Campaña:

Un recetario "De todo con frijoles" (Dumani y Rodríguez 2000) y dos panfletos desplegables que ofrecían información complementaria entre sí. Uno de los panfletos tenía el lema "Los frijoles son ricos, nutritivos y saludables" (número 1) y el otro el lema "Los frijoles son insustituibles. Téngalos siempre en casa" (número 2). Los dos lemas fueron elaborados con base en frases o conceptos que los grupos de mujeres manifestaron en relación con los frijoles.

También se presenta el monitoreo de una de las actividades interactivas realizadas en la comunidad: los puestos promocionales en los supermercados, en donde se ofreció información y degustación de preparaciones con frijoles.

Seguidamente se hace una breve descripción de cada uno de los elementos monitoreados.

\section{1) El Recetario:}

El recetario "De Todo con Frijoles" (Dumani, y Rodríguez 2000) ofrece 23 recetas que incluyen desde ensaladas hasta postres, con los frijoles como ingrediente principal. En cada receta se indica el número de porciones estimadas y la información nutricional por porción, con ilustraciones alusivas a cada receta. Consta de 36 páginas, con un tamaño de 13,8 centímetros de ancho y $21,4 \mathrm{~cm}$ de largo, en papel brillante a todo color.

El contenido del recetario fue planeado con el fin de ofrecer un documento que abordara, desde el punto de vista educativo, soluciones a las barreras relativas al consumo de frijoles identificadas en la etapa del diagnóstico.

En la presentación se plantea el problema de la disminución del consumo de frijoles en la población. El papel de los frijoles en la prevención de algunas
The objective of this work is to assess the development of activities and the suitability of the materials used during Campaign implementation. The elements presented in this article were critical for dissemination of messages during the Campaign.

\section{MATERIALS AND METHODS}

This article presents the results of monitoring a recipe book entitled "De todo con frijoles" (Everything with beans) (Dumani and Rodríguez 2000), and two brochures with complementary information, which were produced for the Campaign. One of them had the slogan "Beans are delicious, nutritional, and healthful" ("Los frijoles son ricos, nutritivos y saludables") (Number 1), and the other one had the slogan "Beans are unique. Have them always at home" ("Los frijoles son insustuibles. Téngalos siempre en casa") (Number 2). The two slogans were written based on phrases or concepts expressed by women's groups in relation to beans.

One of the interactive activities implemented in the community was the promotional stands which were set up in supermarkets, where information and tastings of bean preparations were offered to the public. Monitoring of this activity is also presented here.

Following is a brief description of each one of elements monitored.

\section{1) The recipe book:}

The recipe book "De Todo con Frijoles" (Dumani and Rodríguez, 2000) contains 23 recipes including everything from salads to deserts, using beans as their main ingredient. Each recipe indicates the number of estimated servings and the nutritional information per serving, with suggestive illustrations for each recipe. The recipe book has 36 full-color $13.8 \mathrm{~cm}$ wide and $21.4 \mathrm{~cm}$ long pages, on glossy paper.

The book's content was intended to help remove the barriers to bean consumption identified during initial assessment.

A brief explanation of the bean consumption decrease among the population, the role of beans in preventing some diseases, and their importance in daily nutrition, as well as the purpose of the recipe book, are discussed in its presentation.

It also includes a brief outline on the history of bean production in the country, the grain's most 
enfermedades y su importancia en la alimentación diaria así como una breve explicación del propósito del recetario.

Contiene además una breve reseña sobre la historia de la producción de frijoles en el país, los nutrientes más importantes de los mismos y sus funciones, las buenas prácticas para aprovecharlos mejor (Martínez et al. 2000), así como el uso adecuado de la olla de presión, con el objetivo de neutralizar el temor relacionado con el uso de este utensilio.

\section{2) Panfletos desplegables}

Ambos desplegables están impresos en papel maché tamaño carta, a todo color, y doblados en tres secciones, para dar un total de seis caras. Los dos presentan en su portada el lema que los identifica y dibujos de frijoles "personificados" y en movimiento. En la contraportada, en la mitad inferior, un mensaje clave final y la identificación de la fuente del material.

El panfleto número uno ofrece en las caras internas mensajes con las razones por las que es importante comer frijoles diariamente y recomendaciones prácticas para mejorar el valor nutritivo de los frijoles con su respectiva explicación. El panfleto número dos ofrece consejos relativos a la conservación y al consumo de frijoles, cada uno con su respectiva explicación y tres recetas de preparaciones con frijoles.

En ambos panfletos, hay pequeños dibujos del personaje "frijol" reforzando lo dicho en el texto. Es importante destacar que el dibujo del frijol, utilizado en estos panfletos y en otros materiales, había sido previamente sometido al análisis en grupos focales de niños (as) y de mujeres, quienes sugirieron que presentara las siguientes características: que tuviera "un ombligo" (o sea, el "ojo" del frijol), que tuviera ojos y boca que le dieran expresividad, que sus manos podían ser hojas similares a las de la planta de frijol pero sus pies debían estar cubiertos por zapatos. En la ilustración 1 se presentan dibujos del personaje utilizado.

\section{3) Puestos promocionales}

Puestos promocionales de información y degustación se ubicaron en los tres supermercados que fueron señalados por la población estudiada como los principales puntos de venta de frijoles: Palí de Santa Marta de Montes de Oca, Más x Menos de Sabanilla de Montes de Oca y Súper Cindy, en Cedros de Montes de Oca. Estos puestos se instalaron en días alternativos, los important nutrients and functions, good practices to make the best use of them (Martínez et al. 2000), and the adequate use of the pressure cooker, in order to diminish the fear associated with the use of said utensil.

\section{2) Brochures}

Both brochures are printed on letter-size, full-color glossy paper, and folded in three sections, resulting in a total of six sides. The slogans and "impersonated" moving beans appear on the front cover. In the lower half of the back cover there is a final key message, and the indication of the source of the material presented.

Brochure 1 presents the reasons for which it is important to eat beans every day, and some practical recommendations to improve their nutritional value, with corresponding explanations. Brochure 2 provides advise concerning bean consumption and their preservation at home, each one with its respective explanation, and three recipes using beans.

There are small drawings of the "bean" character in both brochures, reinforcing what the text says. The bean character used in these brochures and in other materials, had been previously analyzed in children's and women's focus groups, where it was suggested that it should have the following characteristics: it had to have a "navel" (i.e., the bean's "eye"); it needed eyes and a mouth to make it expressive; its hands could be leaves similar to those of the bean plant, while its feet had to be covered by shoes. Drawings of the character used are presented in Illustration 1.

\section{3) Promotional stands}

Promotional stands to provide information and tastings, were set up in the three supermarkets that the population studied indicated as the main point of sale for beans: Palí in Santa Marta de Montes de Oca, Más $x$ Menos in Sabanilla de Montes de Oca, and Super Cindy, in Cedros de Montes de Oca. The stands operated in alternating weeks (popularly called "de quincena"), on Saturdays at the middle and end of the month, the dates when people usually go to the supermarket to buy their groceries.

Promotional stands were assisted by two persons involved on the Campaign, whose task was to approach costumers, give them the brochure, talk to them about the importance of bean consumption, offer tastings of bean preparations, and answer any questions or inquiries from people on the subject. 
Ilustración 1

Dibujo del personaje del frijol

Campaña educativa para incrementar el consumo de frijoles Sabanilla de Montes de Oca, Costa Rica, 2000 - 2001

\section{Illustration 1}

Drawings of the Bean Character

Educational Campaign to Increase Bean Consumption Sabanilla de Montes de Oca, Costa Rica, 2000 - 2001.

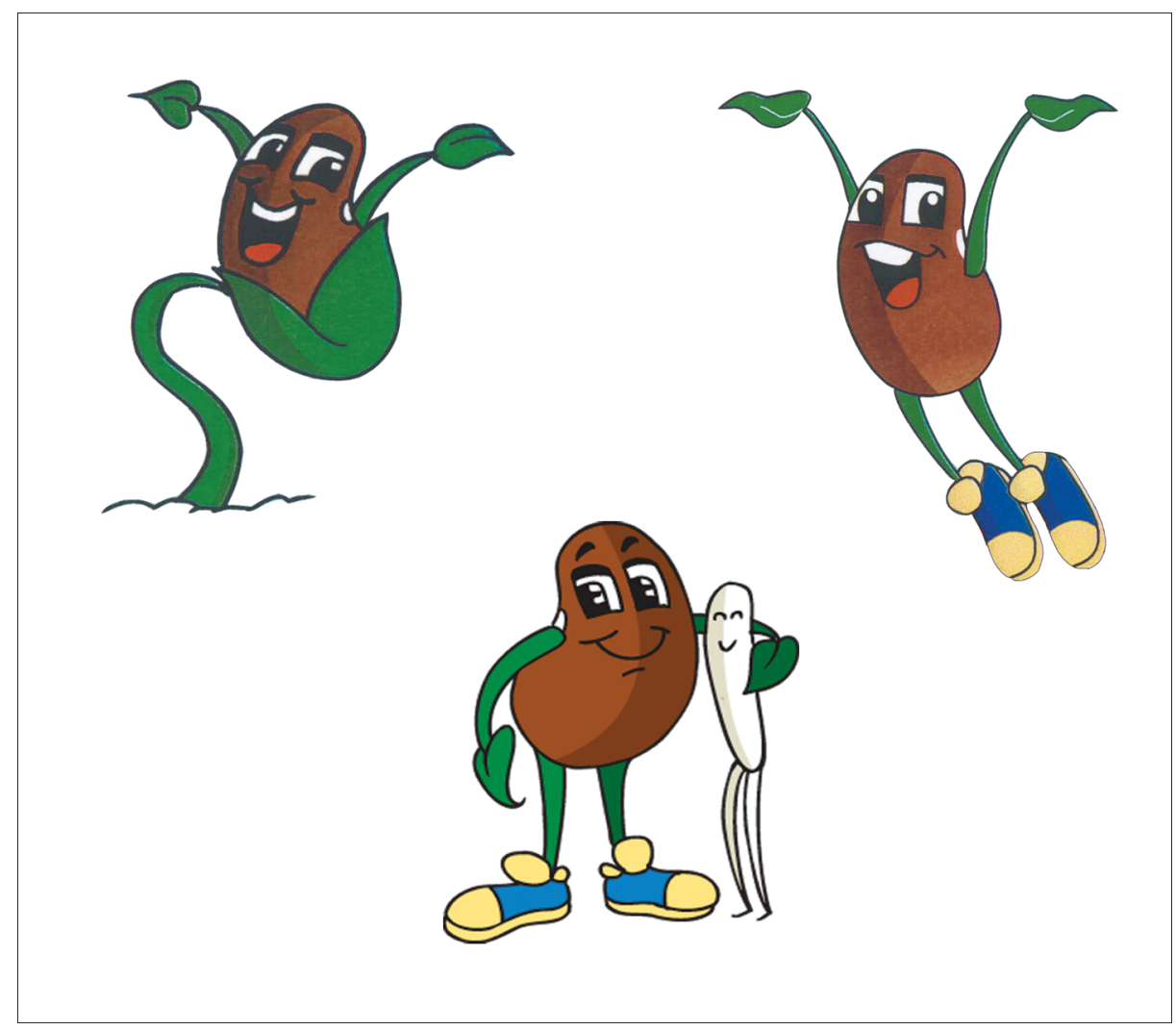

sábados correspondientes a la mitad y el fin de mes (popularmente llamados "de quincena"), pues en esos días es cuando más personas acuden a los supermercados a realizar sus compras.

El puesto promocional fue atendido por dos personas involucradas con la Campaña, cuya labor fue captar a los asistentes, ofrecerles el panfleto, conversar sobre la importancia del consumo de frijoles, ofrecer degustaciones de preparaciones con frijoles y evacuar cualquier consulta o duda que plantearan las personas sobre el tema.

El puesto promocional se montó dos veces en cada punto de venta. Allí fueron atendidas todas las personas que se acercaron al puesto, pero se dio énfasis a las amas de casa. La primera vez se distribuyó el panfleto número uno, la segunda vez el panfleto número dos.
Promotional stands were set up twice in every point of sale. There, everybody that came to the stand was taken care of, but attention focused on housekeepers. Brochure1 was distributed the first time, and brochure 2 was distributed the second time.

\section{Data collection}

Given that monitoring is part of the Campaign's implementation phase ${ }^{6}$, data were collected during or immediately after each interactive activity, and a short time after the materials had been distributed.

6 The Campaign implementation phase lasted six months: from the middle of September through the middle of December, 2000 (with an emphasis on interpersonal communication), and from February through April, 2001 (with an emphasis on mass communication). 


\section{Recolección de datos}

Dado que el monitoreo es parte de la etapa de ejecución de la Campaña ${ }^{6}$, los datos se recogieron durante o inmediatamente después de cada actividad interactiva y poco tiempo después de haber entregado los materiales.

Para conocer la opinión sobre los panfletos desplegables y el recetario fue utilizado un cuestionario - uno para cada tipo de material - para ser llenado personalmente por las madres de escolares que cursaban el tercero y cuarto grados, al momento de ejecución de la Campaña.

En todos los casos, los cuestionarios indagaron sobre la apreciación general en relación con el material, lo que más les gustó del mismo, los aspectos que no les agradaron o que podrían cambiarse o mejorarse, lo que recordaban del contenido, lo que aprendieron y lo que pusieron en práctica.

Los tres tipos de cuestionarios fueron probados previamente con grupos de mujeres de características similares a las del grupo objetivo.

Los datos se obtuvieron de las madres de los escolares que estaban involucrados en la campaña, utilizando una muestra a conveniencia. El recetario fue evaluado por 21 madres, el panfleto No. 1 por 26 y el No. 2 por 23 .

A las madres se les enviaron los panfletos y el recetario, con sus hijos e hijas, y una semana después el cuestionario respectivo. En el caso de los panfletos, los cuestionarios fueron recogidos una semana después. Para el recetario, el cuestionario fue recogido un mes después, con el objeto de dar suficiente tiempo para que las madres practicaran las nuevas recetas.

Debido a que hubo algunos inconvenientes con el envío y la recolección de los cuestionarios por medio de los niños, fue necesario, en varios casos, obtener la información por entrevista telefónica o mediante visita al hogar.

Para el monitoreo de las actividades interactivas realizadas en los puestos promocionales en supermercados, se hizo una sistematización de la experiencia. La persona responsable de cada una de las actividades realizadas llevó a cabo un reporte y la sistematización se elaboró con base en los reportes obtenidos.

\footnotetext{
6 La etapa de ejecución de la Campaña tuvo una duración de seis meses; de medianos de setiembre a mediados de diciembre del año 2000 (énfasis en comunicación interpersonal) y de febrero a abril del año 2001 (énfasis en comunicación masiva).
}

In order to get opinions about the brochures and the recipe book, a questionnaire was used for each material, to be filled out personally by the mothers of school children attending third and fourth grades during Campaign implementation.

In every case, the questionnaires inquired about the general appreciation of the materials, what people liked most about them, the aspects that they did not like or could be changed or improved, what they remembered of their content, what they learned, and what they put into practice.

All three questionnaires were previously tested with groups of women of similar characteristics as those of the target group.

The data were collected from mothers of school children participating in the Campaign, using a sample chosen by convenience. The recipe book was assessed by 21 mothers, brochure 1 by 26 mothers, and brochure 2 by 23 mothers.

The recipe book and brochures were sent to the mothers with their children, and the questionnaire was sent to them one week later. In the case of the brochures, the questionnaires were collected one week later. For the recipe book, the questionnaire was collected one month later, in order for the mothers to have enough time to use the new recipes.

There were some inconveniences when sending and collecting the questionnaires through the children. In those cases it was necessary to get the information by means of a telephone interview or a home visit.

In order to monitor the interactive activities carried out in the promotional stands in supermarkets, the experience was systematized. The person in charge of each one of the activities made a report, and this information was organized into a final report.

\section{RESULTS AND DISCUSSION}

\section{A. Recipe book}

\section{General assessment}

Mothers that answered the questionnaire gave positive opinions about the recipe book. Most of them rated it as "very good", "excellent", "very nice", and some of them even used words such as "complete", "interesting", "wonderful", and "very delicious". 


\section{RESULTADOS Y DISCUSIÓN}

\section{A. Recetario}

\section{Valoración general}

Las madres que respondieron el cuestionario utilizaron calificativos positivos al referirse al recetario. La mayoría lo calificó como "muy bueno", "excelente", "muy lindo", "muy bonito", e incluso algunas utilizaron palabras como "completo", "interesante", "maravilloso", "riquísimo".

Más de la mitad de las mujeres había hecho una lectura completa del recetario, logrando retener una buena cantidad de la información ofrecida, y habían practicado las recomendaciones que allí se daban, lo cual se consideró un resultado satisfactorio. Algunas expresiones que corroboraron la valoración positiva de las mujeres sobre el recetario fueron:

“Es un recetario con información fuera de lo común”. "Sigan haciendo este tipo de información para tener una buena nutrición”.

"Cambia la visión de la utilización del frijol”.

"Los hijos aprenden a comer frijoles, sirvió bastante".

"Está muy completo en información y recetas".

"Son recetas baratas y fáciles".

Varias madres señalaron ciertos atributos del recetario, como por ejemplo: que es claro y sencillo, novedoso, que trae muchas ideas y que las recetas son sencillas.

Otro aspecto señalado por las participantes, aunque en menor grado, fue la forma de presentar la información: explicación sencilla, fácil de asimilar, llamativa, agradable, ingeniosa. Ninguna madre indicó que hubiera algún aspecto que le disgustara del recetario.

Once de las 21 mujeres leyeron y recordaron la información general sobre los frijoles. De ellas, 10 dijeron haber aplicado las nuevas prácticas y de esas diez, nueve las aplicaron siempre.

La información nutricional sobre los frijoles interesó a las madres y les sirvió fundamentalmente para valorarlos como un alimento nutritivo, importante para la salud. Algunas de ellas resaltaron elementos específicos como la fibra y el hierro, la importancia para el crecimiento de los niños y el beneficio de comerlos junto con arroz. Para una, el dato de que los frijoles deben ser consumidos todos los días fue interesante.

Al diseñar el recetario se trató de responder a las observaciones que hicieron las participantes en la etapa
Over half of the women read the entire recipe book, and remembered a fair amount of the information it provided; they put into practice some of the book's recommendations, which is a satisfactory result. Some of the expressions confirming their positive opinions were:

"It is a recipe book with uncommon information".

"Keep on making this type of material to have a good nutrition”.

"It changes your perspective about the use of beans".

"Children learn to eat beans, it was very useful".

"It is comprehensive with regards to information and recipes".

"Recipes are inexpensive and easy to make".

Several mothers indicated certain attributes of the recipe book, for instance, that it is very clear and simple, innovative, it has a lot of ideas, and that the recipes are easy to make.

Another aspect pointed out by participants, although in a lesser degree, was the way the information was presented: straight forward explanations, easy to understand, interesting, appealing, smart. None of the mothers disliked any part of the recipe book.

Eleven of the 21 women read and remembered the general information about beans. Out of them, 10 said that they had implemented the new practices; out of those 10 , nine said that they use them all the time.

Nutritional information on beans caught mother's attention and helped them acknowledge their nutritional value and contribution to health. Some of them pointed out specific elements such as fiber and iron content, their role in children's growth, and the benefit of eating them along with rice. For one of them the recommendation to eat beans on a daily basis turned out to be interesting.

Observations made by participants during initial assessment, about the characteristics that they would expect to find in educational materials and recipes (Campos et al. 1999) were taken into consideration for their design. Acceptance of the materials found in this work, confirms the usefulness of this approach.

Results of this assessment showed that the recipe book was an important tool for the Campaign. It provided general information about beans, and contributed to remove one of the barriers to bean consumption, such as the lack of knowledge about different ways to prepare them. 
diagnóstica en relación con las características que preferían encontrar en un material educativo y en una receta (Campos et al. 1999). La aceptación de los materiales que se encontró en este trabajo, constata la utilidad de este abordaje.

Los resultados de esta valoración demostraron que el recetario constituyó un recurso importante para la Campaña, que además de brindar información general sobre los frijoles, contribuyó a solventar una barrera detectada en relación con el consumo de frijoles, como es el desconocimiento sobre distintas formas de preparación de este alimento.

El recetario, al ofrecer a las lectoras, además de las recetas, información sobre los frijoles, incidió, en los conocimientos, las actitudes y las prácticas de las madres, por lo que fue un instrumento útil en la promoción para un cambio de comportamiento respecto al consumo de frijoles.

En una edición futura de este material, se podría valorar la posibilidad de presentar la información sobre los frijoles de manera que permita captar mejor la atención de las lectoras que no tienen la costumbre de leer textos. Quizás, para cierto sector de la población sería más efectivo incluir junto con las recetas algunos mensajes importantes, tipo "tips" específicos y sin mucho texto.

\section{Valoración de las recetas}

El grado de utilización de las recetas fue satisfactorio: 12 madres (57\%) prepararon más de dos recetas, y de ellas, dos refirieron haberlas preparado todas. Cinco de las 21 mujeres (24\%) dijeron haber preparado una receta o dos. Solamente cuatro de las 21 mujeres no prepararon ninguna receta.

Las recetas fueron aceptadas por el $100 \%$ de las madres. Nueve $(43 \%)$ respondieron que les gustaron todas las recetas y doce madres $(57 \%)$ indicaron que ninguna de las recetas les disgustó, aunque unas les gustaron más que otras. Por ejemplo, preparaciones como la ensalada de frijoles rojos y vainicas (por el sabor), el pudin de frijoles negros (porque "no se animan" a probarlo), los frijoles negros marinados, el rice and beans, y el queque navideño de frijoles rojos (por extraños), no fueron del total agrado de algunas madres.

En relación con las preparaciones preferidas, llama la atención que fueron nombradas tanto recetas tradicionales de nuestra cocina (el pastel de plátano maduro y la sopa negra), como otras muy novedosas (pudín de frijoles y queque navideño), lo cual denota una disposición importante a probar sabores y preparaciones nuevas. Sin
The recipe book had an impact on mothers' knowledge, attitudes, and practices with regards to beans, and therefore was a useful to increase bean consumption.

In a future edition of this material, it would be convenient to present the information in an appropriate way to catch the attention of audiences that do not like to read. Perhaps, for certain population groups it would be more effective to include some messages along with the recipes, such as specific tips with little text.

\section{Assessment of recipes}

The recipes were widely used: 12 mothers (57\%) prepared more than two recipes, and two of them said that they prepared all of them. Five of the 21 women (24\%) said that they prepared one or two recipes. Only 4 of the 21 women did not make any recipes at all.

Recipes were accepted by $100 \%$ of the mothers. Nine $(43 \%)$, answered that they liked all the recipes, and 12 of them $(57 \%)$ indicated that they "did not dislike any of the recipes", although they liked some more than others. Recipes not entirely accepted by some mothers were the red and green bean salad (due to its taste), the black bean pudding (because people "did not dare" to taste it), the marinated black beans, the rice and beans made with coconut oil, and the red bean Christmas cake (because they were unfamiliar with it).

Concerning preferred recipes, women mentioned traditional Costa Rican recipes (ripe plantain cake and black soup), and others more innovative (bean pudding and Christmas cake), which indicates an important disposition to try new flavors and recipes. However, mothers showed a greater resistance to prepare and consume the recipes that meant a greater change with respect to the more traditional ways to eat them, or those that introduced flavors that were very "different from the expected".

These results suggest that the closer a recipe is to the alimentary habits, the more accepted it will be, even if it proposes variations in its ingredients or cooking techniques. It is possible that preparation of new recipes will start with the more traditional ones, gradually leading people to experiment with newer ones. Mothers' motivation and the reinforcement they may receive about the messages sent to them, play an important role in this process.

In order to facilitate a gradual progress in the modification of habits in further campaigns, it is 
embargo, las madres mostraron mayor resistencia a la preparación y consumo de las recetas que planteaban un mayor cambio en relación con las maneras tradicionales de comer los frijoles, o aquellas que introducían sabores muy diferentes a "los esperados".

Estos resultados sugieren que entre más cercana esté una receta a la costumbre alimentaria, mayor será su aceptación, aunque planteé variaciones en ingredientes o en técnicas culinarias. Es posible que la preparación de nuevas recetas se inicie con las más tradicionales y poco a poco avance hacia la experimentación de las más novedosas, en un proceso gradual. En este proceso juega un papel muy importante la motivación de la persona y el refuerzo de los mensajes (por medios masivos o interactivos).

Se sugiere que para futuras campañas, se elaboren dos recetarios que faciliten el avance paulatino en los cambios de prácticas: el primero con recetas más tradicionales y el segundo con recetas novedosas.

\section{Aspectos mejorables}

Solamente hubo una sugerencia en relación con las recetas: "Agregar culantro a la sopa de frijoles rojos con ayote sazón”.

Resulta interesante que la mayoría de las madres expresaron que les gustaría otro recetario similar sobre otro alimento, lo cual demuestra la importancia de que existan recetarios para alimentos específicos, relevantes en la alimentación de la población, que brinden información lo más completa posible sobre el producto y que aporte soluciones a las distintas barreras para su consumo.

\section{B. Panfletos}

\section{Valoración general}

La mayoría de las mujeres dieron los siguientes calificativos a los panfletos: "excelente", "muy bueno", "excelente idea", "importante", "interesante", "forma divertida", "necesario".

Resulta interesante la importancia que dieron las madres al hecho de que el material dirigido a ellas (por la presentación del contenido y las ilustraciones) fuera también llamativo para los niños (as), por lo que se convierte en una herramienta educativa para enseñar nutrición en el hogar. Las madres también valoraron que la vía de entrega de los materiales fueran sus hijos (as), ya que esto propició el interés de ellos por el tema. suggested that two recipe books be made: the first one with traditional recipes, and the second with more innovative recipes.

\section{Aspects to improve}

There was only one suggestion concerning the recipes: "To add cilantro to the red bean and pumpkin soup".

Most mothers said they would like to get similar recipe books about other foods. This shows that it would be important to produce recipe books for specific foods, preferably those that are relevant for the population's nutrition, providing readers with the most complete information possible on the product, and solutions to the different barriers to its consumption.

\section{B. Brochures}

\section{General assessment}

Most women gave the following opinions about the brochures: "excellent", "very good", "excellent idea", "important", "interesting", "entertaining", "necessary".

The fact that the materials addressed to mothers were also appealing for their children (because of their content presentation and illustrations), was particularly important for the mothers, as they could use them as educational tools to teach nutrition at home. Mothers also appreciated the fact that their children were in charge of bringing the materials to them, because this encouraged their interest on the subject. Moreover, it is necessary to keep in mind that during initial assessment (Campos et al. 1999) mothers suggested that materials should "get directly to their hands". This was accomplished by sending the recipe books and brochures to them with their children.

With regards to what they liked the most about the brochures, most mothers indicated that it was the drawings. Several mothers expressed that the little bean drawing (See Illustration 1) made it easier for them to explain their children about the importance of eating beans, and convince them to do so. Also the colors and presentation of the brochures were mentioned in second place, as aspects they liked.

Other mothers indicated that the information, content, and explanations were what they liked most, and four said that they liked everything. 
Además hay que recordar que en el diagnóstico (Campos et al. 1999), las madres habían recomendado que el material debía llegarles "directamente a sus manos", lo que se cumplió mediante el envío del recetario y los panfletos por medio de sus hijos.

En cuanto a lo que más les gustó de los panfletos, la mayoría de las madres indicaron que fueron los dibujos. Varias expresaron que el dibujo del frijolito (Lámina 1), facilita a la madre explicar y convencer al niño(a) acerca de la importancia de consumir frijoles. Así mismo el color y la forma de presentación de los panfletos, fueron señalados en segundo lugar, como aspectos que más les gustaban.

Otras madres indicaron que la información, el contenido y la forma de explicar fue lo que más les gustó y cuatro contestaron que les había gustado todo.

Esto refleja que los panfletos cumplieron con las características que debe tener un material educativo, donde los mensajes deben ser claros, sencillos y que expliquen el por qué de las cosas. Todas estas características habían sido señaladas por los grupos de mujeres que participaron el diagnóstico. Se confirma así la importancia de a partir de un diagnóstico para elaborar los materiales y de probarlos, antes de proceder a su reproducción (FAO 1996).

En relación con la retención de los conceptos y las prácticas contenidas en los panfletos, las madres recordaron aspectos relativos a la importancia, el beneficio y las ventajas del consumo de los frijoles, reconociendo este alimento como "muy nutritivo", "esencial", "importante en la dieta diaria", "necesario", "beneficioso para la salud", "que previene enfermedades", "versátil".

Lo anterior se refleja en frases escritas por las mujeres, como por ejemplo:

"Que se debe incorporar en la dieta diaria al frijol". "Que en todas las formas posibles debemos consumir este alimento".

"Consumo diario y varias veces al día."

"Aprendí a incluirlos más en la dieta."

Otro aspecto importante que recordaban las mujeres, se relaciona con los métodos y técnicas de cocción, conservación y consumo, resaltando el uso de la olla de presión, la conservación por congelación y la complementariedad proteica con el arroz.

En relación con el panfleto número dos, las recetas incluidas fueron muy bien valoradas por las madres, apuntando este aspecto como lo que más les gustó y lo que más recuerdan de este material específico.
This shows that the brochures fulfilled the characteristics of educational materials, where messages must be clear, simple, and explanatory. All these characteristics were mentioned by women's groups participating in the initial assessment. In this way, the importance of starting from an initial assessment to make the materials, and test them before ordering reproduction, was confirmed.

With regards to retention of concepts and practices included in the brochures, mothers remembered aspects about the importance, benefits, and advantages of bean consumption, acknowledging this food as "highly nutritious", "essential", "important in daily diet", "necessary", "healthful", "adaptable", and "good to prevent diseases".

Women used all these qualifying words in phrases they wrote such as:

\footnotetext{
"Beans must be included in daily diet".

"We must eat beans in every way possible".

"We must eat beans every day, and several times a day".

"I learned to include them more in my diet".
}

Another important aspect that women remembered was related to cooking, preservation, and consumption methods and techniques, highlighting use of the pressure cooker, preservation through freezing, and their protein complementary value when combined with rice.

Concerning brochure 2, the recipes included were highly appreciated by the mothers, who indicated that this was the aspect that they liked and remembered the most of this specific material.

The team that implemented the educational Campaign considered that inserting recipes in brochures would probably increase the chance of mothers keeping and using them, more than if the brochure only had information about a specific food. In addition, recipes could motivate women to make more bean-based preparations, thus increasing the frequency of consumption.

\section{Aspects to be improved}

To improve the brochures, mothers made only a few, yet important recommendations. Among them, they suggested to include recipes with beans in brochure 1 , and one of the mothers indicated that less ingredients should be used in the recipes. They also suggested the use of this teaching approach for other 
En este sentido, el grupo de trabajo de la Campaña consideró que probablemente la inclusión de recetas en un panfleto educativo favorece que las madres lo conserven y lo utilicen más que si fuera un panfleto solamente con información sobre un alimento. Además, las recetas podrían motivar la práctica de elaborar más preparaciones con frijoles y así aumentar la frecuencia de consumo de este alimento.

\section{Aspectos mejorables}

Los aspectos sugeridos por las madres para mejorar los panfletos son pocos pero importantes. Entre las recomendaciones propusieron incluir recetas de frijoles en el panfleto número uno y una de las madres señaló que deberían ser utilizados menos ingredientes en las recetas. Además, sugirieron aplicar esta forma de educación con otros alimentos, idea que también propusieron en el caso del recetario.

Resalta el interés de las entrevistadas por información práctica, explicada de manera sencilla, fácil de leer y ligada a su cotidianidad. La receta es un elemento completamente práctico, que se puede replicar en cualquier momento. Según Bourges (1988), los hábitos se forman a partir de la práctica repetida y la receta lo permite.

Ambos panfletos cumplieron con dar información y formación a las lectoras para la modificación de prácticas relacionadas con la preparación, consumo y conservación de los frijoles. También es evidente que abordaron y dieron respuesta a varias de las barreras detectadas en el diagnóstico, que afectaban el consumo de este alimento en esa población.

El diagnóstico (Campos et al. 1999) había revelado que a la población objetivo le faltaba información sobre un alimento tan relevante en la dieta del costarricense como los frijoles.

Las valoraciones hechas por las madres en este trabajo revelaron que el material que se les entregó durante la Campaña cumple con los objetivos de informar y formar a las lectoras, porque les proporciona información desconocida por ellas y las motiva para lograr el objetivo central de la Campaña: incrementar el consumo de frijoles. Por lo tanto, se confirma la importancia de haber producido este material educativo.

\section{Puestos promocionales}

El monitoreo de los puestos promocionales de información y degustación en los supermercados permitió: foods, an idea that was also recommended in the case of the recipe book.

The women interviewed showed great interest for practical information, explained in simple terms, easy to read and related to their daily lives. Recipes are entirely practical and could be reproduced at any time. According to Bourges (1988), habits are established by repeated practice, something that may be accomplished by following recipes.

Both brochures fulfilled their purpose of providing information and instruction to readers, helping them to modify their practices with regards to bean preparation, consumption, and preservation. These brochures evidently addressed several of the barriers to bean consumption detected during the initial assessment.

The initial assessment (Campos et al. 1999) showed that the target population lacked information about this food that is so important in the Costa Rican diet. Mothers' assessments reveal that the materials fulfilled the objectives of informing and instructing them, since such materials provided them with information that they did not have before, and motivated them to achieve the Campaign's main objective: to increase bean consumption, thus confirming the importance of producing this educational material.

\section{Promotional stands}

Monitoring of promotional stands contributed to understand that::

- Highly frequented spots, such as aisles and common areas near cash registers are the best places to locate promotional stands, instead of next to the aisle where the beans are placed, as was originally planned.

- $\quad$ Promotional stands and attendants must be clearly identified. Since the work team was from the University of Costa Rica, the supermarket customers approached them with confidence, and were more receptive to the information offered to them, because they knew the stands had an educational, rather than a business purpose.

- The University of Costa Rica enjoys great prestige and credibility among the people. Therefore, identification with the institution was very important to carry out this educational activity, and at the same time it entailed a great responsibility on the part of the research team. 
- Comprender que el mejor sitio para colocar el puesto era en un lugar con bastante afluencia de personas, como en un pasillo general o al frente, en el área común cerca de las cajas registradoras y no como originalmente se planificó contiguo a la góndola donde están los frijoles.

- Reconocer que el puesto promocional y las personas que los atienden deben de estar claramente identificadas. En este caso por ser el grupo de trabajo de la Universidad de Costa Rica, los clientes del supermercado se acercaron y fueron más receptivos a la información que se les brindaba ya que sabían que no había un interés comercial sino educativo.

- Reafirmar el prestigio y credibilidad que tiene la Universidad de Costa Rica entre nuestra población. Por eso la identificación con la institución fue de gran importancia para el desarrollo de esta actividad educativa. Por esa razón, implicó también mucha responsabilidad de parte de quienes desarrollaron la actividad.

- Determinar que en general, los dueños o administradores de los supermercados manifestaron agrado por la actividad y fueron buenos colaboradores.

- Reconocer la contribución de esta actividad en la transmisión de los mensajes y particularmente en superar el mito de las limitaciones en las formas de preparación que pueda tener un alimento tan tradicional como los frijoles, lo que se logró mediante la degustación de preparaciones poco usuales.

- Valorar la importancia de tener disponibles todos los materiales escritos correspondientes a la Campaña, ya que difícilmente las personas que acuden un día al supermercado podrán ser captadas otro día. En este sentido, la no disponibilidad del recetario en ese momento constituyó una limitación, pues los asistentes al puesto tenían interés de contar con las recetas de las preparaciones que degustaron.

- Identificar que los supermercados constituyen sitios importantes para llevar a cabo una actividad educativa nutricional, ya que la gran afluencia de personas favorece la interrelación requerida con la población.

- Determinar que las actividades interactivas son un componente importante en una campaña educativa, ya que el contacto directo con la población, permite evacuar dudas y generar infomación adicional sobre las percepciones de las personas en relación con el alimento que se promueve (FAO 1996).
- In general, the supermarket owners or managers were pleased with the activity, and were willing to collaborate.

- Promotional stands are important to promote the messages, and in particular, to help break away from the myth about the limited ways to prepare beans, which was achieved through tastings of uncommon preparations.

- It is important to have all Campaign's written materials at hand, because people that come one day to the supermarket can hardly be contacted another day. In this sense, the fact that recipe books were not available at the stands was a limitation, because when people tasted the different preparations offered at the stands and asked for the recipes, they could not be given to them.

- Supermarkets are important places to carry out nutritional education activities, because of the large number of people who visit them, which facilitates establishing contact with them.

- Interactive activities are an important component in an educational Campaign, because direct contact with the population provides the opportunity to respond to any questions that may arise, and additional knowledge about people's perceptions concerning the food being promoted may be obtained (FAO 1996).

In conclusion, the fact that the materials and educational activities were made and planned according to the criteria and opinions from people who participated in the initial assessment, facilitated these materials and activities to be widely accepted, thus becoming valuable tools to achieve the Campaign's objectives.

\section{REFERENCES}

BOURGES, H. 1998. Costumbres, prácticas y hábitos alimentarios deseables e indeseables. Archivos Latinoamericanos de Nutrición 39 (3): 767-779.

CAMPOS, E; FERNÁNDEZ, A; SÁNCHEZ, I; SANCHO, T.; VILlALOBOS, C. 1999. Diagnóstico para una Campaña educativa para aumentar el consumo de frijol en una comunidad del área urbana de clase media. Seminario de Licenciatura. San José, Costa Rica: Universidad de Costa Rica.153 p.

COHEN, E.; FRANCO, R. 1997. Evaluación de proyectos sociales. $2^{\text {da }}$ ed. Madrid, España. Siglo XXI Editores. p. 319. 
En conclusión, la elaboración de los materiales y la planificación de las actividades educativas, respetando los criterios y las opiniones de la población que participó en el diagnóstico, permitió que las mismas fueran ampliamente aceptadas y constituyeran instrumentos valiosos para alcanzar los objetivos de la Campaña.

\section{LITERATURA CITADA}

BOURGES, H. 1988. Costumbres, prácticas y hábitos alimentarios deseables e indeseables. Archivos Latinoamericanos de Nutrición 39 (3): 767-779.

CAMPOS, E; FERNÁNDEZ, A; SÁNCHEZ, I; SANCHO, T.; VILLALOBOS, C. 1999. Diagnóstico para una Campaña educativa para aumentar el consumo de frijol en una comunidad del área urbana de clase media. Seminario de Licenciatura. San José, Costa Rica: Universidad de Costa Rica.153 p.

COHEN, E.; FRANCO, R. 1997. Evaluación de proyectos sociales. $2^{\text {da }}$ ed. Madrid, España: Siglo XXI Editores. p. 319 .

DUMANI M.; RODRÍGUEZ S. 2000. De todo con frijoles. San José, Costa Rica: Universidad de Costa Rica, Escuela de Nutrición/CITA-Programa Bean Cowpea CRSP-AID. p. 35.

FAO. 1993. Guidelines for participatory nutrition proyects. Cap. Monitoring and evaluation of participatory nutrition proyects. Rome, Italy: FAO, p. 66-80.

1995. Manejo de proyectos de alimentación y nutrición en comunidades. Guía didáctica. Unidad 10. Roma. Italia: FAO, p. 143-166.

. 1996. Guía metodológica de comunicación social en nutrición. Roma. Italia. p. 101.

MARTÍNEZ, T.; MURILLO, A.; PÁEZ, P.; RODRÍGUEZ, S. 2000. Elaboración de los contenidos de los mensajes de una Campaña educativa para aumentar el consumo de frijol en una comunidad del área urbana de clase media. Seminario de Licenciatura. San José, Costa Rica: Universidad de Costa Rica. 103 p.
DUMANI M.; RODRÍGUEZ S. 2000. De todo con frijoles. San José, Costa Rica: Universidad de Costa Rica, Escuela de Nutrición/CITA-Programa Bean Cowpea CRSP-AID. p. 35.

FAO. 1993. Guidelines for participatory nutrition proyects. Cap. Monitoring and evaluation of participatory nutrition proyects. Rome, Italy: FAO, p. 66-80.

1995. Manejo de proyectos de alimentación y nutrición en comunidades. Guía didáctica. Unidad 10. Roma. Italia: FAO, p. 143-166.

1996. Guía metodológica de comunicación social en nutrición. Roma. Italia. p. 101.

MARTÍNEZ, T.; MURILLO, A.; PÁEZ, P.; RODRÍGUEZ, S. 2000. Elaboración de los contenidos de los mensajes de una Campaña educativa para aumentar el consumo de frijol en una comunidad del área urbana de clase media. Seminario de Licenciatura. San José, Costa Rica: Universidad de Costa Rica. 103 p. 